\title{
Regulation of glucose transporter protein-1 and vascular endothelial growth factor by hypoxia inducible factor $1 \alpha$ under hypoxic conditions in Hep-2 human cells
}

\author{
OU XU ${ }^{1,2}$, XIAOMING LI ${ }^{1,2}$, YONGTAO QU ${ }^{2}$, SHUANG LIU ${ }^{3}$, JIE AN $^{3}$, MAOXIN WANG $^{2}$, QINGJIA SUN $^{2}$, \\ WEN ZHANG ${ }^{3}$, XIUYING LU $^{2}$, LIHONG PI ${ }^{2}$, MIN ZHANG $^{2}$ and YUPENG SHEN ${ }^{2}$ \\ ${ }^{1}$ Department of Otorhinolaryngology, Hebei Medical University, Shijiazhuang, Hebei 050017; \\ Departments of ${ }^{2}$ Otorhinolaryngology Head Neck Surgery and ${ }^{3}$ Pathology, \\ Bethune International Peace Hospital, Shijiazhuang, Hebei 050082, P.R. China
}

Received April 3, 2012; Accepted August 2, 2012

DOI: $10.3892 / \mathrm{mmr} .2012 .1075$

\begin{abstract}
The present study evaluated the regulation of glucose transporter protein-1 (Glut-1) and vascular endothelial growth factor (VEGF) by hypoxia inducible factor $1 \alpha$ (HIF-1 $\alpha$ ) under hypoxic conditions in Hep-2 human cells to explore the feasibility of these three genes as tumor markers. Hep-2 cells were cultured under hypoxic and normoxic conditions for $6,12,24,36$ and $48 \mathrm{~h}$. The proliferation of Hep-2 cells was evaluated using an MTT assay. The protein and mRNA expression levels of HIF-1 $\alpha$, Glut-1 and VEGF were detected using the S-P immunocytochemical method, western blotting and reverse transcription polymerase chain reaction (RT-PCR). The results revealed that the expression levels of HIF-1 $\alpha$, Glut-1 and VEGF protein in Hep-2 cells were significantly elevated under hypoxic conditions compared with those under normoxic conditions over $36 \mathrm{~h}$. Under hypoxic conditions, mRNA levels of HIF-1 $\alpha$ were stable, while mRNA levels of Glut-1 and VEGF changed over time. In conclusion, Glut-1 and VEGF were upregulated by HIF-1 $\alpha$ under hypoxic conditions in a time-dependent manner in Hep-2 cells and their co-expression serves as a tumor marker.
\end{abstract}

Correspondence to: Professor Xiaoming Li, Department of Otorhinolaryngology Head Neck Surgery, Bethune International Peace Hospital, 398 Zhongshan West Road, Shijiazhuang, Hebei 050082, P.R. China or Department of Otorhinolaryngology, Hebei Medical University, 361 Zhongshan East Road, Shijiazhuang, Hebei 050017, P.R. China

E-mail:xmlmo@126.com

Key words: hypoxia inducible factor $1 \alpha$, glucose transporter protein-1, vascular endothelial growth factor, immunocytochemistry, reverse transcription polymerase chain reaction

\section{Introduction}

Head and neck squamous cell carcinoma (HNSCC) is the sixth most common malignant tumor worldwide (1). Its clinicopathological characteristics include an insidious onset, strong invasiveness and the liability of recurrence and metastasis with poor prognosis. Although improvements in therapeutic strategies have been made in the past 2-3 decades, the overall five-year survival rate remains almost unchanged. The main reasons for this are considered to be post-treatment locoregional recurrence, distant metastasis and inherent therapeutic resistance to chemoradiation and newly developed molecularly targeted therapy, which is affected by numerous tumoral microenvironmental factors. Among these factors, hypoxia in tumors is thought to be closely correlated with the therapeutic resistance of various types of human cancer.

Hypoxia inducible factor $1 \alpha$ (HIF-1 $\alpha$ ), a key regulator of hypoxia, promotes the expression of more than 100 genes related to angiogenesis, cell proliferation, glucose metabolism, erythropoiesis and cell survival rate (2). Previous studies have demonstrated that the expression of HIF- $1 \alpha$ in HNSCC is associated with a poor response to radiotherapy and an adverse prognosis (3). As a downstream factor of HIF-1 $\alpha$, glucose transporter protein-1 (Glut-1; encoded by the SLC2A1 gene in humans) is ubiquitously expressed in a number of solid tumors. Previous studies have demonstrated that the suppression of SLC2A1 expression by antisense oligodeoxynucleotides decreases glucose uptake and inhibits the proliferation of Hep-2 cells. The expression level of Glut-1 has been correlated with poor prognosis in a variety of tumors and is responsible for resistance to therapy (4). The study by Sullu et al demonstrated that vascular endothelial growth factor (VEGF) appears to be vital in the metastatic process of HNSCC (5).

Although the expression of HIF-1 $\alpha$, Glut-1 and VEGF has been investigated under hypoxia in laryngeal carcinoma (LC) Hep-2 cells, the regulatory mechanisms have not been explored and thus the role of hypoxia in Hep-2 cells remains unclear. Therefore, we evaluated the expression of HIF- $1 \alpha$, Glut- 1 and VEGF at the protein and transcriptional levels in Hep-2 cells under hypoxia to examine their regulation and explore the 


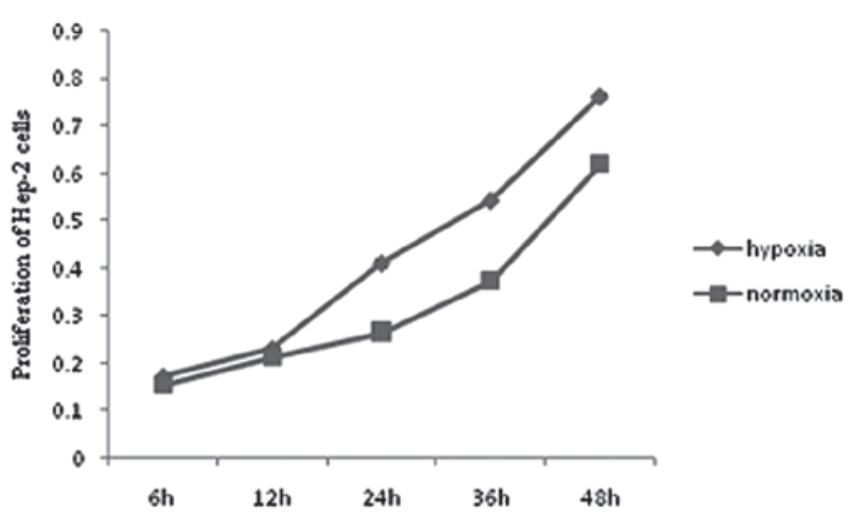

Figure 1. The proliferation of Hep-2 cells under hypoxic and normoxic conditions.

feasibility of using these three genes as markers of hypoxia in tumors.

\section{Materials and methods}

Cell culture. The present study was conducted at the Department of Otorhinolaryngology Head and Neck Surgery in Bethune International Peace Hospital, China, and was approved by the ethics committee of Bethune International Peace Hospital.

Hep-2 cells (Chinese Acadamy of Science, Shanghai Institute for Life Sciences, Cell Resource Center, China) were cultured in complete RPMI-1640 medium (Gibco, Carlsbad, CA, USA) containing 10\% calf serum (Hangzhou Sijiqing Biology Engineering Materials Co. Ltd., China) under conditions of $37^{\circ} \mathrm{C}, 5 \% \mathrm{CO}_{2}$ and $95 \%$ humidity in a carbon dioxide incubator. Hep-2 cells were divided into 5 experimental and 5 control groups when they had reached the logarithmic phase. The experimental groups were cultured under hypoxic conditions $\left(5 \% \mathrm{CO}_{2}, 1 \% \mathrm{O}_{2}\right.$ and $\left.94 \% \mathrm{~N}_{2}\right)$ for $6,12,24,36$ and $48 \mathrm{~h}$. The control groups were cultured under normoxic conditions $\left(5 \% \mathrm{CO}_{2}, 20 \% \mathrm{O}_{2}\right.$ and $75 \% \mathrm{~N}_{2}$ ) according to the durations of the experimental groups. Cells were then collected for the subsequent detection method following termination of cultivation.

MTT assay. Hep-2 cells were grown in 96-well plates at a density of $5 \times 10^{3} / 200 \mu 1$. When all cells had adhered to the plate, they were incubated under various conditions. Following incubation, $20 \mu \mathrm{l}$ MTT (5 mg/ml, Sigma, St. Louis, MO, USA) was added to each well and left for $4 \mathrm{~h}$ prior to adding $150 \mu \mathrm{l}$ DMSO. The 96-well plate was then put into an Enzyme-linked Immunosorbent Detector (Model 550, Bio-Rad, Hercules, CA, USA) with absorbance values of $490 \mathrm{~nm}$ (A490) to detect cell viability. A cell proliferation curve was graphed according to the absorbance values, with time values on the $\mathrm{X}$-axis and absorbance values on the Y-axis.

Immunocytochemistry. For immunohistocytochemical analysis, 6-well plates were used, in which three small pieces of cover glass were placed. Single cell suspensions were prepared at a concentration of $1 \times 10^{6}$ cells/ml using RPMI-1640 medium. A drop of cell suspension was seeded onto the glass. Cells were grown in an incubator under normoxic conditions overnight to allow the adherence of the majority of cells to the cover glass. Each well was supplemented with $2 \mathrm{ml}$ of RPMI-1640 medium and cultured under various conditions according to the experimental design. Following the termination of culturing, the Hep-2 cells were collected for immunohistocytochemical study. The cover glass was washed with PBS twice, fixed with cold acetone for $10 \mathrm{~min}$, incubated with $3 \% \mathrm{H}_{2} \mathrm{O}_{2}$ for $20 \mathrm{~min}$ at room temperature (RT), incubated with goat serum for $20 \mathrm{~min}$ at $37^{\circ} \mathrm{C}$, incubated with primary antibody (rabbit antihuman HIF-1 $\alpha$ polyclonal antibody, rabbit anti-human Glut-1 polyclonal antibody, rabbit anti-human VEGF polyclonal antibody; Santa Cruz Biotechnology Inc., Santa Cruz, CA, USA; dilution ratio 1: 50) overnight, washed with PBS, incubated with goat-anti-rabbit antibody for $15 \mathrm{~min}$ at RT and dropped with horseradish-peroxidase-labeled pronase avidin for $15 \mathrm{~min}$ at RT and 3,3'-diaminobenzidine (DAB) reagent for $<1 \mathrm{~min}$. Cells were then redyed with hematoxylin, dehydrated with gradient alcohol and sealed with neutral resin. For the negative controls, PBS was used rather than the primary antibodies. Under an optical microscope (x400), optical density values were measured using Image Pro Plus Software (Media Cybernetics Inc., Bethesda, MD, USA), selecting 5 visions randomly on each cover glass.

Western blotting. Equal amounts of Hep-2 cell lysates (30 $\mu \mathrm{g})$ were separated using 10-12\% SDS-polyacrylamide gel electrophoresis (SDS-PAGE), transferred to a $0.45 \mu \mathrm{m}$ PVDF membrane, blocked in $5 \%$ skimmed milk for $2 \mathrm{~h}$ at $37^{\circ} \mathrm{C}$, incubated with primary antibodies (dilution ratio 1:200) overnight at $4^{\circ} \mathrm{C}$, washed three times in Tris-buffered saline with $0.25 \%$ Tween-20 (TBST), incubated with the appropriate anti-rabbit secondary antibodies (Beijing Zhongshan Goldenbridge Bio-technology Co. Ltd., Beijing, China; 1:5,000) diluted in TBST blocking buffer for $1 \mathrm{~h}$ at RT, washed three times with TBST and detected with PRN2132 Amersham Enhanced Chemiluminescence (ECL) Plus Western Blotting Detection System (GE Healthcare Life Sciences, Hatfield, UK). The bands were exposed to film in a dark chamber and densitometry was evaluated using a gel image analyzing system (UVP, LLC, Upland, CA, USA).

$R T$-PCR. Total RNA was isolated from Hep-2 cells with TRIzol reagent (Invitrogen, Carlsbad, CA, USA) and then reverse transcribed with the oligo dT primer (Invitrogen). The sequence of PCR primers used is not shown. The conditions of RT-PCR for HIF-1 $\alpha$ and Glut-1 were as follows: initial denaturation at $94^{\circ} \mathrm{C}$ for $1 \mathrm{~min}$, annealing at $60^{\circ} \mathrm{C}$ for $1 \mathrm{~min}$, polymerization at $72^{\circ} \mathrm{C}$ for $2 \mathrm{~min}\left(35\right.$ cycles) and terminal extension at $72^{\circ} \mathrm{C}$ for $10 \mathrm{~min}$. RT-PCR conditions for VEGF were as follows: initial denaturation at $94^{\circ} \mathrm{C}$ for $1 \mathrm{~min}$, annealing at $56^{\circ} \mathrm{C}$ for $1 \mathrm{~min}$, polymerization at $72^{\circ} \mathrm{C}$ for $2.5 \mathrm{~min}$ (35 cycles) and terminal extension at $72^{\circ} \mathrm{C}$ for $10 \mathrm{~min}$. The products were resolved in $1.5 \%$ agarose gels containing $0.5 \mathrm{mg} / \mathrm{ml}$ ethidium bromide. The optical density was assessed using a gel image analysis system. The ratio of the target gene to the $\beta$-actin gene in each group was semiquantitatively determined.

Statistical analysis. The data are expressed as the mean \pm standard deviation (mean \pm SD). One-way ANOVA was used to determine any statistical differences between the experi- 

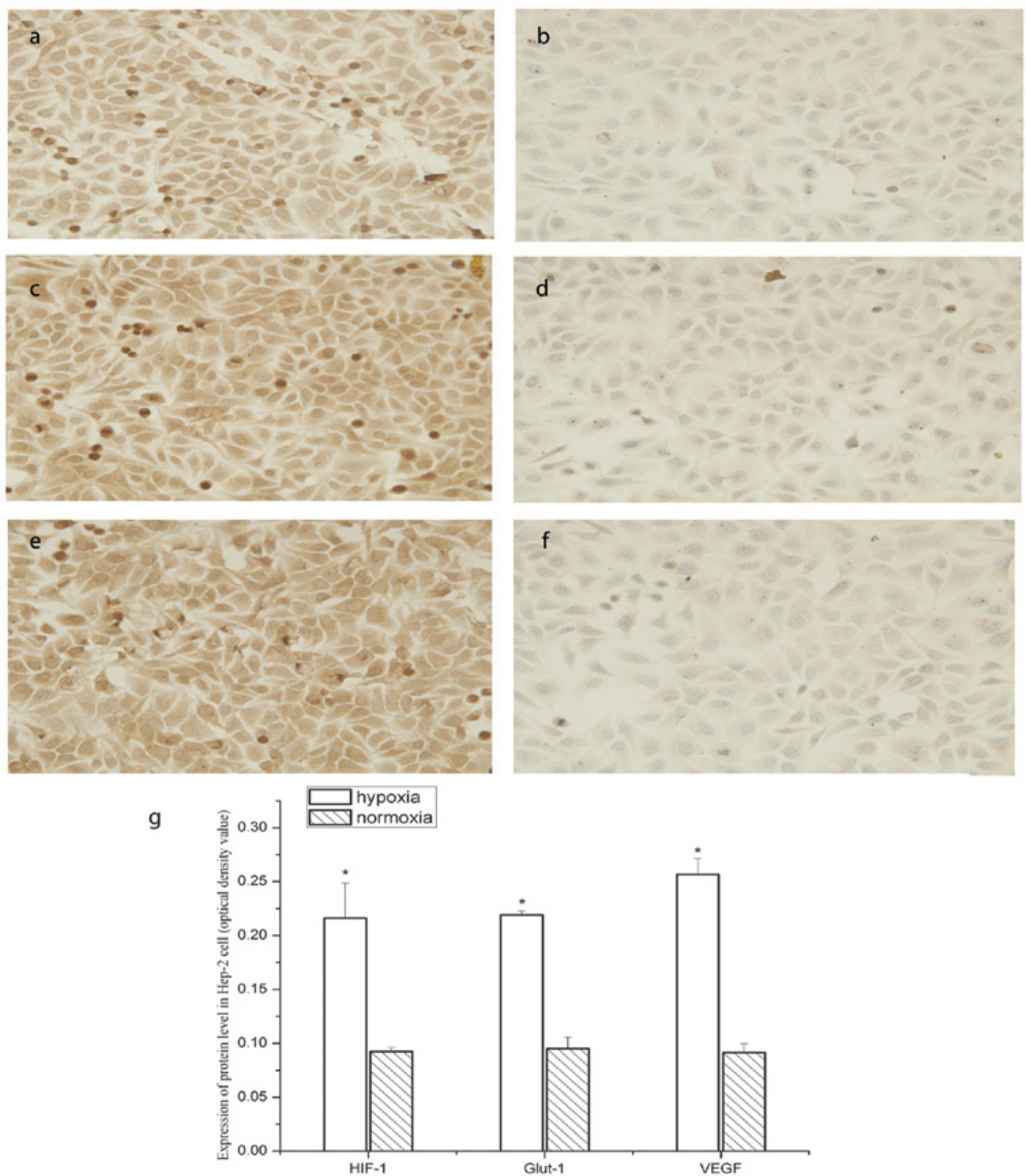

Figure 2. The expression of HIF-1 $\alpha$, Glut-1 and VEGF protein in laryngeal squamous cell carcinoma Hep-2 cells. (a) Positive expression of HIF-1 $\alpha$ under hypoxic conditions; (b) negative expression of HIF-1 $\alpha$ under normoxic conditions; (c) positive expression of Glut-1 under hypoxic conditions; (d) negative expression of Glut-1 under normoxic conditions; (e) positive expression of VEGF under hypoxic conditions; (f) negative expression of VEGF under normoxic conditions; (g) histogram of the expression of HIF-1 $\alpha$, Glut-1 and VEGF protein in Hep-2 cells. HIF-1 $\alpha$, hypoxia inducible factor 1 $\alpha$; Glut-1, glucose transporter protein-1; VEGF, vascular endothelial growth factor.

mental groups. The Neuman-Keuls multiple comparisons procedure was used to determine the differences between the two groups. Statistical comparisons were performed with SPSS 13.0 software for Windows and $\mathrm{P}<0.05$ was considered to indicate statistically significant differences.

\section{Results}

Proliferation of Hep-2 cells. The growth rate of Hep-2 cells was increased under hypoxic compared with normoxic conditions during the 48-h study $(\mathrm{P}<0.05)$. At the onset of the study, the proliferation rate of Hep- 2 cells under hypoxia was slightly elevated. The difference in the growth rate between hypoxic and normoxic conditions increased as time progressed (Fig. 1).

Expression of HIF-1 $\alpha$, Glut-1 and VEGF in Hep-2 cells. The correlation between the expression of HIF- $1 \alpha$ and Glut-1 or VEGF was first investigated in Hep-2 cells. The immunocy- tochemical results revealed that HIF-1 $\alpha$ was mainly located in the cytoplasm or nucleus, Glut-1 was mainly located in the cytoplasm or cytomembrane and VEGF was located in the cytoplasm. Under hypoxic conditions, the expression levels of the HIF-1 $\alpha$, Glut-1 and VEGF proteins were significantly increased $(\mathrm{P}<0.05)$. The protein expression levels reached a peak at approximately $36 \mathrm{~h}$ of hypoxia and then decreased after $48 \mathrm{~h}$. A positive correlation was observed between protein expression of HIF-1 $\alpha$ and Glut-1 or VEGF in Hep-2 cells (Fig. 2).

Western blot analysis revealed that the expression of HIF-1 $\alpha$, Glut-1 and VEGF protein increased gradually under hypoxic conditions and peaked at $36 \mathrm{~h}$, which was consistent with the immunocytochemical results (Fig. 3).

Effect of expression of HIF-1 $\alpha$ on Glut-1 and VEGF genes under hypoxia. RT-PCR results revealed that the mRNA levels of HIF-1 $\alpha$ did not change under hypoxic conditions, while the mRNA expression levels of Glut-1 and VEGF were upregu- 
$6 \mathrm{~h}$ control $12 \mathrm{~h}$ control $24 \mathrm{~h}$ control $36 \mathrm{hcontrol} 48 \mathrm{~h}$ control
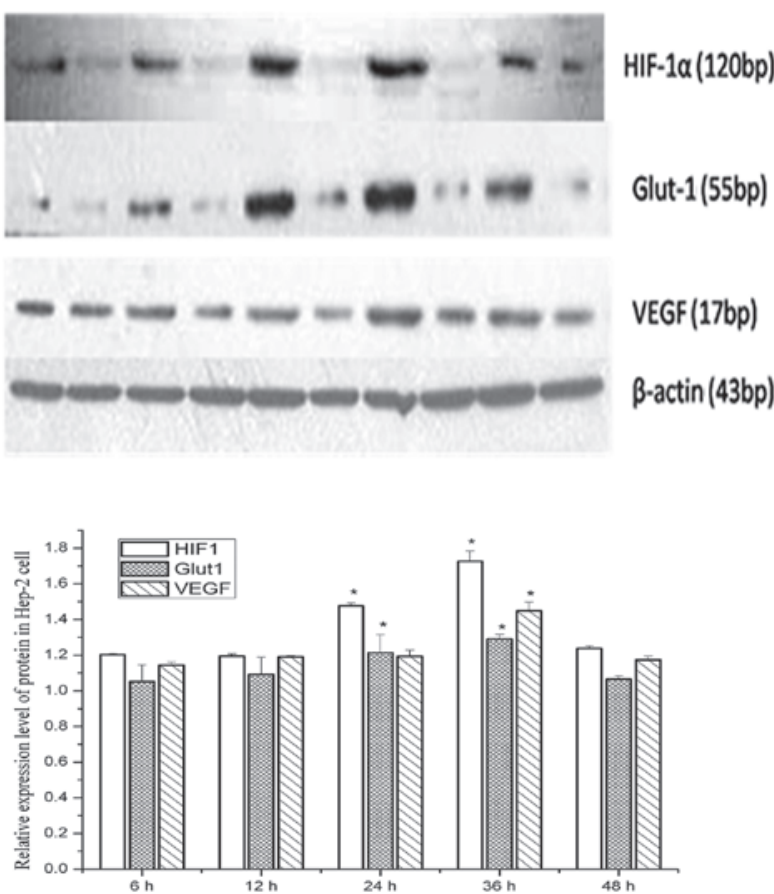

Figure 3. Western blotting results showing expression levels of HIF-1 $\alpha$, Glut-1 and VEGF protein in laryngeal squamous cell carcinoma Hep-2 cells. Under hypoxic conditions, the expression levels of HIF-1 $\alpha$, Glut-1 and VEGF all gradually increased to higher than those observed under normoxic conditions. Protein expression peaked at $36 \mathrm{~h}$ of hypoxia and descended at $48 \mathrm{~h}$. HIF-1 $\alpha$, hypoxia inducible factor $1 \alpha$; Glut-1, glucose transporter protein-1; VEGF, vascular endothelial growth factor

lated $(\mathrm{P}<0.05)$. The mRNA levels of Glut-1 and VEGF peaked at $36 \mathrm{~h}$ (Fig. 4).

\section{Discussion}

Hypoxia renders tumor cells more invasive for metastatic phenotypes and resistant to radiochemotherapy, which is attributed to the modification of factors related to angiogenesis, metastasis and resistance to apoptosis as well as therapy. Among these factors, HIF- $1 \alpha$ is significant. The regulation of hypoxia on HIF-1 $\alpha$ expression was considered to occur at the post-transcriptional level, which reflected its reduced degradation and elevated binding to DNA (6). However, other studies have reported that the expression of HIF-1 $\alpha$ mRNA was higher under hypoxia and the regulation of HIF- $1 \alpha$ occurred at the transcriptional level prior to protein alteration (7). The reason that these conclusions are inconsistent may be a difference of oxygen partial pressure $\left(\mathrm{PO}_{2}\right)$ and cell line types. The results of the present study demonstrated that the majority of the HIF-1 $\alpha$ protein was accumulated during the first $12 \mathrm{~h}$, followed by steady expression during 12-36 $\mathrm{h}$ and finally expression was downregulated at $48 \mathrm{~h}$ of hypoxia. Expression peaked at $36 \mathrm{~h}$. Notably, the mRNA level was stable under hypoxia. This suggests that the regulation of HIF-1 $\alpha$ under moderately hypoxic conditions (1\% oxygen) in Hep-2 cells occurred at the translational level.

That HIF-1 $\alpha$ accumulated in a time-dependent manner under moderate hypoxia and degraded gradually after $36 \mathrm{~h}$ of
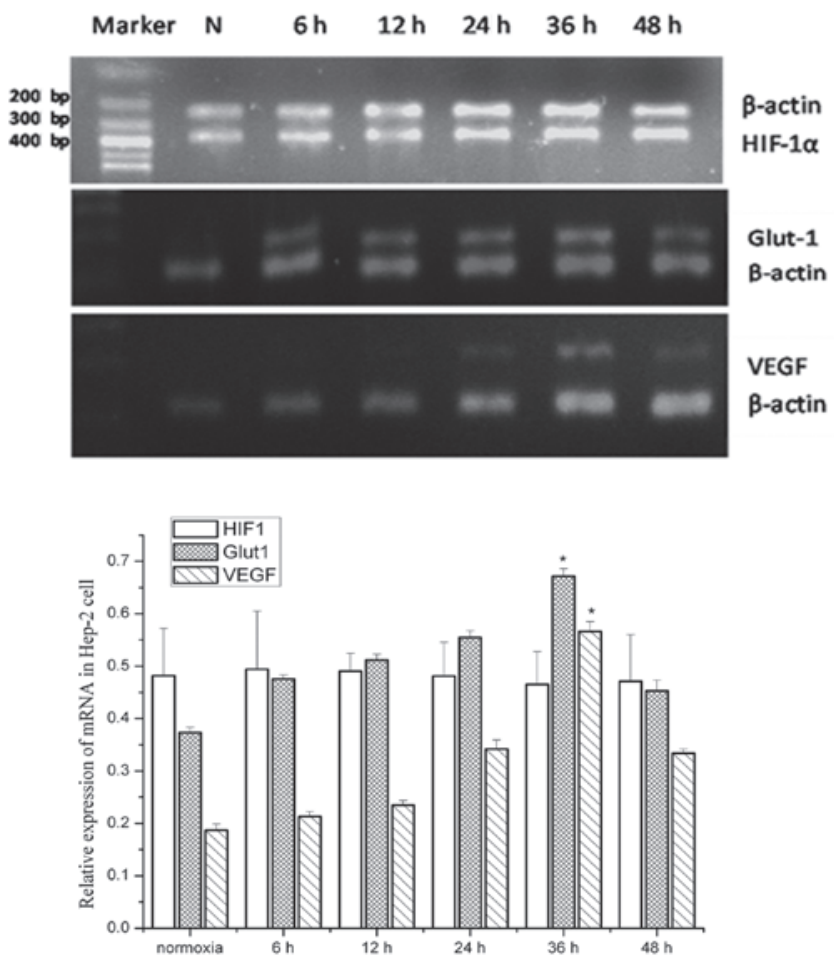

Figure 4. Effect of expression of HIF-1 $\alpha$ on Glut-1 and VEGF genes under hypoxia. Under hypoxic conditions, the mRNA level of HIF-1 $\alpha$ was almost equal to that under normoxic conditions. Under hypoxic conditions, the mRNA levels of Glut-1 and VEGF were increased, suggesting that the regulation of Glut-1 and VEGF by HIF-1 $\alpha$ in laryngeal squamous cell carcinoma occurred at the transcriptional level. ${ }^{*} \mathrm{P}<0.05$ comparing the three genes under hypoxic versus normoxic conditions. Bars represent mean and standard error of the mean (SEM) from three independent experiments. HIF-1 $\alpha$, hypoxia inducible factor $1 \alpha$; Glut-1, glucose transporter protein-1; VEGF, vascular endothelial growth factor.

hypoxia may be correlated with the following three aspects. Firstly, HIF is the key regulator of hypoxia in tumor cells and its degradation is completed by proteasomes via the conjunction of the $\mathrm{O}_{2}$-dependent HIF prolyl hydroxylase (PHD) enzyme with its $\alpha$ subunit which is then polyubiquitinated; this is inhibited when oxygen concentrations decrease below 5\%. Hypoxia induces the reduction of PHD activity, downregulates HIF-1 $\alpha$ degradation and increases its accumulation (6). Secondly, there is an oxygen-dependent degradation domain (ODD) located in the 401-603 region of HIF-1 $\alpha$. Under chronically hypoxic conditions, HIF- $1 \alpha$ transformation subordinates to a 2-4 $\mathrm{h}$ half-life and the degradation of proteasomes requires an entire ODD. This leads to the degradation time of HIF-1 $\alpha$ being prolonged. With the accumulation of protein increasing and its degradation decreasing, the quantity of HIF-1 $\alpha$ reaches saturation. When Hep-2 cells are cultured continuously, cellular metabolism may be altered leading to cell death. Thus, in the current study the expression level of HIF-1 $\alpha$ was downregulated after $36 \mathrm{~h}$ of hypoxia.

When the tumor microenvironment is under hypoxic conditions, Glut-1 and glycolytic enzymes are activated by multiple cancer genes and growth factors. This promotes the increased uptake and transport of glucose to meet cell energy requirements for fast proliferation. Immunohistochemical examination has revealed that Glut-1 is ubiquitously overexpressed in a number of tumors (8), including breast, thyroid, 
hypopharynx, bladder and lung cancer. The expression of Glut-1 is correlated with a poor prognosis of breast, colorectal and lung cancer. The expression of Glut-1 is increased in liver cancer, which promotes tumorigenesis (9). In the current study, the protein and mRNA levels of Glut-1 were elevated under hypoxic conditions, followed by HIF-1 $\alpha$ accumulation due to increased expression. This then combines with the promoter and enhancer on Glut-1 mRNA, leading to Glut-1 transcription to maintain the metabolism of tumor cells and supply them with a material foundation for further growth and metastasis. Glut-1 is mainly regulated by HIF- $1 \alpha$; however, it is also affected by other regulators (10).

VEGF, a specific mitogen of vascular endothelial cells, stimulates the formation of new vessels. Its expression is transcriptionally induced in hypoxic tissues through the action of HIF-1 $\alpha$ and is involved in adaptive processes, including angiogenesis and neuroprotection (11). The present study revealed that the protein expression and mRNA levels of VEGF were dynamically upregulated under hypoxic conditions. However, certain data demonstrate that VEGF is regulated by multiple intracellular pathways in a tumor cell and its genesis also occurs in the absence of HIF-1 $\alpha$. STAT3 is activated under hypoxia by reactive oxygen species (ROS) which then bind to the promoter of the VEGF gene, as HIF-1 $\alpha$ does under hypoxia (12). The stress-induced unfolded protein response of the endoplasmic reticulum also activates VEGF expression (13). It remains to be determined whether VEGF activation and overexpression are mediated by these pathways in Hep-2 cells in addition to HIF-1 $\alpha$ signaling.

In conclusion, HIF-1 $\alpha$, Glut-1 and VEGF were co-expressed under hypoxic conditions in human Hep-2 cells. Their expression level was tightly correlated with oxygen concentration and culture time. HIF-1 $\alpha$ is significant for upregulating Glut-1 and VEGF expression under hypoxia. HIF-1 $\alpha$, Glut-1 and VEGF jointly act as an intrinsic marker of tumor hypoxia in LC. Their expressions are closely related to tumor metabolism and metastasis, which may help define the biological features and predict the prognosis of laryngeal squamous carcinoma.

\section{Acknowledgements}

The present study was supported in part by the National Natural Science Research Fund (no. 30572029), China and the Wu Jieping Medical Research Foundation (no. 320.6750.10121), China.

\section{References}

1. Jemal A, Siegel R, Ward E, Murray T, Xu J, Smigal C and Thun MJ: Cancer statistics. CA Cancer J Clin 56: 106-130, 2006.

2. Semenza GL: Targeting HIF-1 for cancer therapy. Nat Rev Cancer 3: 721-732, 2003.

3. Koukourakis MI, Giatromanolaki A, Sivridis E, Pastorek J, Karapantzos I, Gatter KC and Harris AL; Tumour and Angiogenesis Research Group: Hypoxia-activated tumor pathways of angiogenesis and $\mathrm{pH}$ regulation independent of anemia in head-and-neck cancer. Int J Radiat Oncol Biol Phys 59: 67-71, 2004.

4. Luo XM, Zhou SH and Fan J: Glucose transporter-1 as a new therapeutic target in laryngeal carcinoma. J Int Med Res 38: 1885-1892, 2010

5. Sullu Y, Gun S, Atmaca S, Karagoz F and Kandemir B: Poor prognostic clinicopathologic features correlate with VEGF expression but not with PTEN expression in squamous cell carcinoma of the larynx. Diagn Pathol 5: 35, 2010.

6. Huang LE, Gu J, Schau M and Bunn HF: Regulation of hypoxiainducible factor $1 \alpha$ is mediated by an $\mathrm{O}_{2}$-dependent degradation domain via the ubiquitinproteasome pathway. Proc Natl Acad Sci USA 95: 7987-7992, 1998.

7. Zhong H,Agani F,Baccala AA, Laughner E, Rioseco-CamachoN, Isaacs WB, Simons JW and Semenza GL: Increased expression of hypoxia inducible factor-1a in rat and human prostate cancer. Cancer Res 58: 5280-5284, 1998.

8. Mayer A, Höckel M, Wree A and Vaupel P: Microregional expression of glucose transporter-1 and oxygenation status: lack of correlation in locally advanced cervical cancers. Clin Cancer Res 11: 2768-2773, 2005.

9. Amann T, Maegdefrau U, Hartmann A, Agaimy A, Marienhagen J, Weiss TS, Stoeltzing O, Warnecke C, Schölmerich J, Oefner PJ, et al: GLUT1 expression is increased in hepatocellular carcinoma and promotes tumorigenesis. Am J Pathol 174: 1544-1552, 2009.

10. Robey IF, Stephen RM, Brown KS, Baggett BK, Gatenby RA and Gillies RJ: Regulation of the Warburg effect in early-passage breast cancer cells. Neoplasia 10: 745-756, 2008.

11. Harms KM, Li L and Cunningham LA: Murine neural stem/progenitor cells protect neurons against ischemia by HIF-lalpha-regulated VEGF signaling. PLoS One 5: e9767, 2010

12. Rathinavelu A, Narasimhan $M$ and Muthumani P: A novel regulation of VEGF expression by HIF- $1 \alpha$ and STAT3 in HDM2 transfected prostate cancer cells. J Cell Mol Med: Oct 18, 2011 (Epub ahead of print).

13. Du H, Li W, Wang Y, Chen S and Zhang Y: Celecoxib induces cell apoptosis coupled with up-regulation of the expression of VEGF by a mechanism involving ER stress in human colorectal cancer cells. Oncol Rep 26: 495-502, 2011. 